\title{
EL DERECHO A LA INTIMIDAD PERSONAL EN EL ÁMBITO LABORAL
}

\author{
Isabel SÁENZ-TORRE DE TORRE
}

GRADUADA EN DERECHO

UNIVERSIDAD DE LA RIOJA

SUMARIO: I. Introducción. I.I. Aproximación a los Derechos Fundamentales. I.2. Rasgos básicos del Derecho a la Intimidad Personal y Familiar. II. El Derecho a la Intimidad Personal en el ámbito laboral. II.r. Introducción. II.2. Colisión de derechos con el poder empresarial en el centro de trabajo. II.3. Colisión de derechos con el poder empresarial en el centro de trabajo. II.4. Problemática del empleo de los medios de control por parte de la empresa. III. El Derecho a la Intimidad y los avances informáticos. IV. Conclusiones.

RESUMEN: Este trabajo versa sobre el derecho a la intimidad en el ámbito laboral. El estudio de los conflictos que surgen al poner en relación el derecho a la intimidad de los trabajadores con los instrumentos de control del empresario alcanza tanto a su actividad laboral como a la extralaboral y pone de relieve la insuficiente regulación de la cuestión en el ordenamiento español. El delicado equilibrio que ha de observarse entre ambos derechos ha dado lugar a una amplia jurisprudencia, no siempre compatible entre sí, sobre todo con la aparición de las tecnologías de la información y la comunicación (TICs), que examina la prevalencia que ha de darse a uno u otro derecho, atendiendo a los intereses que han de ser protegidos.

Palabras Clave: Derecho a la intimidad. Control empresarial. Videovigilancia. Tecnologías de la infocomunicación.

ABSTRACT: This project deals with the workers right to privacy within the workplace. The study deals with the conflicts that emerge when dealing with the privacy of workers right with the employer's instruments of control that involves both, work activities and ultimately after-work activities of the employee, furthermore, this highlights the insufficient regulation of the topic in the Spanish legal system. The delicate act of balance needs to be observed between both employee and employers rights, has led to an extensive case-law, a times contradicting each other, especially with the emergence of information and communication technologies (ITC). This case-law examines the prevalence that has to be conceded to one or another right, depending on the interests that must be protected.

KEY WORDS: Privacy. Management control rights. Video surveillance. Information and communication technology. 


\section{Introducción}

\section{I.I. Aproximación a los Derechos Fundamentales}

Los Derechos Fundamentales (DDFF) son derechos positivizados y garantizados por las constituciones normativas. Sus características, por lo tanto, están ligadas a la propia norma que los origina y los fundamenta, que en nuestro caso es la Constitución Española como norma jurídica suprema.

Aunque no hay una definición exacta, gran parte de la doctrina entiende que son «aquellos derechos humanos garantizados por el ordenamiento jurídico positivo, en la mayor parte de los casos en su normativa constitucional». Sin embargo, para otra parte de la doctrina esta definición se centra demasiado en el plano de la positividad y consideran los DDFF como «la resultante de las exigencias de la filosofía de los derechos humanos con su plasmación normativa en el derecho positivo»².

Otros autores en cambio los definen como «todos aquellos derechos que la Constitución garantiza a los ciudadanos como expresión o traducción, en el ordenamiento positivo nacional, de los derechos del hombre, derechos humanos o derechos inviolables». En este sentido se afirma que los DDFF son derechos constitucionales, entendidos como derechos subjetivos dotados de la fuerza normativa propia de la Constitución Española (CE), específicamente de una constitución que se impone de modo efectivo a todos los poderes públicos, y al propio legislador ${ }^{3}$. Por lo tanto, se suele subrayar que los DDFF serían aquellos derechos que reúnan tres características, a saber: que se trate de derechos enunciados en el texto constitucional, que sean derechos subjetivos exigibles inmediatamente ante los tribunales ordinarios y que estén dotados de una especial resistencia al legislador, que se concreta en este caso en el respeto del contenido esencial del derecho (art.53.I CE) .

En consonancia con esto, hay que remarcar que es innegable la íntima relación entre el Estado de Derecho y los DDFF. Por ello cumplen una misión de fundamento y límite de todas las normas que organizan el funcionamiento de los poderes públicos.

Estos derechos se encuentran recogidos en el Título I de la CE, concretamente en el Capítulo II y para su defensa se creó una protección excepcional pues se rodean de las máximas garantías constitucionales, donde el legislador debe respetar su contenido esencial (art. 53.I CE) y se dispone para ellos la institución del amparo y la reserva a un tipo específico de ley, pues necesitan una Ley Orgánica (LO) para su desarrollo (art. 8I CE),

\footnotetext{
I Surgió un debate doctrinal acerca de su fundamento material, donde las dos corrientes eran el iusnaturalismo, que defendía que eran derechos inherentes al hombre, y el iuspositivismo, que consideraba que eran derechos en tanto que venían reconocidos en un ordenamiento jurídico.

Se acaba por adoptar una posición intermedia, que aboga por creer que los derechos humanos tienen una raíz pre-normativa pues son conjuntos de valores asumidos por la sociedad, que por su normativización en sede constituyente se convierten en derechos fundamentales.

2 PÉrez LuÑo, A., Derechos humanos, Estado de Derecho y Constitución, Madrid, 20io, pág. 33.

3 Aragón Reyes, M., Aguado Renedo, C., Derechos Fundamentales y su protección, Pamplona, 2oir, pág. 24.

4 Biglino, P., Bilbao, J., Rey, F., Matia, J., Lecciones de Derecho Constitucional II, Pamplona, 2OI3, págs. 4OI404 .
} 
además de un procedimiento agravado de reforma que se equipara a la revisión total de la CE.

\section{I.2. Rasgos básicos del Derecho a la Intimidad Personal y Familiar}

El art. I8.I CE, estipula que «se garantiza el derecho al honor, a la intimidad personal y familiar y a la propia imagen». En este artículo se reconocen tres DDFF diferentes, cada uno con su contenido propio e independiente, ya que son derechos autónomos. Estos derechos se desarrollan en la Ley Orgánica I/I982, de 5 de mayo, que regula su ejercicio, aunque esta ley no diferencia entre los tres derechos sino que los trata de manera conjunta.

El derecho a la intimidad se vincula con la esfera más reservada de las personas, al ámbito que estas preservan de las miradas ajenas, por lo que hace referencia a una obligación de los poderes públicos y de la sociedad de respetar un ámbito de privacidad en la persona.

La titularidad del derecho se atribuye a todas las personas, tanto nacionales como extranjeras, y protege al individuo aisladamente considerado, pero también a su núcleo familiar, como personas con las que se mantiene una especial vinculación.

El problema que surge es determinar qué sea lo íntimo, y cuál el espacio de intimidad, ya que este no deja de ser un espacio subjetivo indeterminado, al no aparecer definido ni en la CE, ni en la LO I/1982 de 5 de mayo. Por esto, el Tribunal Constitucional (TC) señala que la intimidad constitucionalmente garantizada se refiere a un ámbito propio y reservado frente a la acción y conocimiento de los demás, según las pautas de nuestra cultura para mantener una calidad mínima de vida humana 5 .

No obstante, el concepto de intimidad, no es inmutable a lo largo del tiempo, sino que viene marcado, de manera decisiva, por las ideas que prevalezcan en cada momento en la sociedad.

Actualmente, la doctrina constitucional considera que el derecho a la intimidad personal y familiar viene integrado por la intimidad corporal (STC 37/1989, de I5 de febrero, FJ. 7), la sexualidad (STC 89/1987, de 3 de junio, FJ. 2), la intimidad económica (STC IIo/I984, de 26 de noviembre, FJ. 3), la propia muerte (STC 23I/I988, de 2 de diciembre, FJ. 4) y las relaciones conyugales y familiares (STC 45/1989, de 20 de febrero, FJ. 9) $)^{6}$.

Hay que concretar, como dice VALDÉS DE LA VEGA, que «el derecho a la intimidad tiene que ver, en su aspecto externo, con un espacio en el cual la persona deposita sus elementos privados, un espacio en el cual desarrolla su esfera privada» ${ }^{7}$. En el ámbito de

\footnotetext{
5 En este sentido, véanse las sentencias del TC 89/2006, de 27 de marzo, I76/2013 de 2I de octubre y I90/20I3, de I8 de noviembre.

6 Serrano Olivares, R., «El derecho a la intimidad como derecho de autonomía personal en la relación laboral», Revista Española de Derecho del Trabajo, núm. I03, 200I, págs. I02-I03.

7 VAldÉs De LA VeGa, B., «El derecho a la intimidad y su expectativa de respeto en el uso personal de las tecnologías de la información y comunicación en el trabajo. Un comentario a la sentencia del Tribunal Supremo de 26 de septiembre de 2007 y a la doctrina del Tribunal Europeo de Derechos Humanos», Revista de Derecho Social, núm.42, 2008, pág. I45.
} 
privacidad es donde el individuo vive sin estar sujeto necesariamente a los usos y convenciones sociales y donde, en consecuencia, ejerce su libertad más íntima.

En lo referente a la legislación, la LO I/I982, en su artículo 7, plasma una lista de intromisiones ilegítimas en la intimidad. Estas son, en general, el emplazamiento y utilización de aparatos de escucha o filmación para el conocimiento de la vida íntima de las personas, la divulgación de hechos relativos a la vida privada y la revelación de datos privados conocidos a través de la actividad profesional.

Estos cuatro supuestos no constituyen una lista cerrada ni exhaustiva de intromisiones ilegítimas, por lo que cabrían más supuestos.

La LO también deja claro en su artículo 2 que la protección de este derecho queda delimitada por las leyes y los usos sociales, y que se atenderá al ámbito que, por sus propios actos, mantenga cada persona para sí misma y para su familia.

No será lo mismo para una persona que ejerce un cargo público o una profesión de notoriedad o proyección pública que para una persona privada. Esto no quiere decir que la primera tenga reducido el espacio de intimidad, sino que debe soportar un grado de intromisión mayor ${ }^{8}$.

Pero aun respecto a la misma persona que ejerce un cargo público, el concepto de intimidad, referido a la captación o reproducción de su imagen variará según se encuentre en un acto público o en un lugar abierto al público, como regulan los artículos 7 y 8 de la citada Ley Orgánica.

En cuanto a los límites, hay que distinguir entre la delimitación del derecho que hace la CE, la LO que lo configura y los límites marcados por la jurisprudencia por su colisión o conflicto con otros derechos $\mathrm{u}$ otros bienes protegidos.

Hay que añadir que la intervención legislativa puede suponer una ampliación o restricción del derecho. Esta intervención tiende a completar la regulación plasmada por la $\mathrm{CE}$, si bien cualquier medida tendente a reducir la aplicabilidad potencial del derecho en cuestión deberá respetar el contenido esencial, hallarse justificada por la necesidad de proteger otro derecho fundamental o bien constitucionalmente protegido y superar el test de proporcionalidad.

Y es que, como indica JIMÉNEZ CAMPO «el precepto constitucional está admitiendo que al legislador le corresponde un margen de intervención sobre los derechos, mientras no suponga una invasión de su contenido inderogable, desde el momento en que los DDFF requieran ser definidos o delimitados por normas infraordenadas» ${ }^{9}$.

\footnotetext{
8 En este orden la STC 7/20I4, de 27 de enero, reconoce la violación del derecho a la intimidad de una revista por la difusión de imágenes que afectaban a artistas, y ello pese a que estas personas tuvieran una vida pública, dado que la intimidad como derecho queda afectada cuando se invade una esfera de privacidad no consentida.

Las SSTC 89/2006, de 27 de marzo y I73/20II, de 7 de noviembre, dejan claro que cada persona puede reservarse un espacio resguardado de la curiosidad o el conocimiento ajeno que a cada uno le corresponde acotar.

9 Jimenez CAmpo, J. «El legislador de los Derechos Fundamentales», Estudios de Derecho Público en homenaje a Ignacio de Otto, Universidad de Oviedo, I993, pág. 504.
} 
Por lo que cabe decir que la CE plasma el primer límite en el contenido esencial regulado en el art. 53.I CE, que vincula específicamente al legislador ${ }^{\text {To }}$

Otro límite enmarcado en el preámbulo de la $\mathrm{LO}$ I/I982, de 5 de mayo, es el interés general.

Este abarca varias acepciones, pues no se podrá alegar cuando se ponga en peligro la seguridad nacional, cuando se atente contra el orden público, la salud o las buenas costumbres y, sin duda, cuando su ejercicio pueda violentar los derechos y las libertades del resto de los individuos. Esto conlleva un delicado equilibrio entre los intereses de la comunidad en su conjunto (encarnados en el Estado) y el ámbito de lo estrictamente privado ${ }^{\text {II }}$.

Por otro lado, existen unos límites jurisprudenciales que se han ido desarrollando como consecuencia de que el derecho a la intimidad tiene, como todos los DDFF, unos límites difusos, por lo que colisiona además con varios derechos. Esto ya lo explico el TC cuando expuso que todo derecho tiene sus límites que a veces se encontraban en la propia CE y que en otros casos derivan de ella de una manera indirecta, en tanto que también habrá de proteger otros bienes constitucionalmente protegidos ${ }^{\mathrm{I} 2}$.

La jurisprudencia se encarga de delimitar la colisión con otros derechos. El propio art. 20.4 CE establece el respeto a la intimidad personal y familiar, al honor la propia imagen y la protección de la juventud y la infancia frente a las libertades de expresión y comunicación, aunque es la jurisprudencia la que marca los criterios.

Otro derecho en conflicto es la libertad de información, donde habrá que hacer una ponderación para ver si existe un interés público suficiente que defienda la publicación de esa información.

Hay otros supuestos de colisión donde la intimidad tiene que ceder ante otros bienes constitucionalmente protegidos, como por ejemplo las investigaciones sobre paternidad, la protección de los hijos, controles fiscales de la Hacienda Pública...

Por último, el derecho a la intimidad puede colisionar con otros derechos o bienes jurídicos en el ámbito laboral, donde habrá que ver qué está justificado por ser necesario para el control de una actividad laboral y qué no lo está y por eso supone una violación del derecho a la intimidad.

\footnotetext{
IO Si bien es cierto que los criterios para valorar si se vulnera el contenido esencial son desarrollados por la jurisprudencia. Entre ellos:

- La limitación debe ser razonable (SSTC 53/1986, de 5 de mayo y I20/1990, de 27 de junio).

- Deben ser racionales y adecuados a la consecución del fin perseguido (STC 62/1982, de I5 de octubre).

- La restricción ha de ser proporcional (SSTC 37/I989, de I5 de febrero y I20/1990, de 27 de junio)

${ }^{\text {II }}$ En este orden, en las SSTC I99/20I3, de 5 de diciembre, 23/20I4, de I3 de febrero y 135/20I4, de 8 de septiembre, el Tribunal rechaza que se vulnere el derecho a la intimidad, pues defiende que supone una injerencia en este derecho orientada a la consecución de un fin constitucionalmente legítimo, citando además al TEDH cuando explica que «ya hemos dejado constancia de que el TEDH ha considerado legítima la práctica de estos análisis cuando está destinada a vincular a una persona determinada con un delito concreto que se sospecha que ha cometido».

Por lo que, en estos casos, se superponen la seguridad nacional y los intereses de los demás individuos al derecho a la intimidad de los recurrentes.

I2 En este sentido, SSTC 2/I982, de 29 de enero, II/I98I, de 8 de abril y iıo/ı984, de i6 de noviembre.
} 
Este último es el objeto del artículo y lo que pasa a analizarse a continuación.

\section{El derecho a la intimidad personal en el ámbito laboral}

\section{II.I. Introducción}

Dentro de los DDFF que defiende la CE, el derecho de huelga y el derecho a la sindicación poseen un contenido laboral en la mayoría de las ocasiones. Otros dos derechos, como son el de igualdad y el de no discriminación, encuentran en la relación de trabajo una clara aplicación. Por último, la mayoría de los demás derechos tienen su vertiente laboral, pues pueden repercutir en las relaciones individuales y colectivas de trabajo, como son la libertad ideológica, la libertad de expresión o el derecho a la intimidad ${ }^{\text {13 }}$.

El progresivo aumento de la tecnología relativa a la captación y transmisión de imágenes y sonidos, susceptibles de un uso fraudulento o delictivo, recurriendo especialmente a sistemas de alta tecnología, ha ido generando una legislación garantista que intenta proteger la imagen y la voz de las personas frente a estos nuevos escenarios. Lo mismo ocurre con la aparición de los ordenadores, el correo electrónico e incluso las redes sociales.

El ámbito laboral también se ve afectado por esta tecnología, donde los derechos de los trabajadores se pueden ver vulnerados, de ahí la amplia jurisprudencia que se ha ido creando con base en el art. I8 CE y en la LO 2/1982, de 5 de mayo, sobre protección civil del derecho al honor, a la intimidad personal y familiar y a la propia imagen.

Se han ido introduciendo sistemas de control en la producción de bienes y servicios que, si pueden ser en parte necesarios para un desarrollo normalizado de determinadas actividades productivas, suponen una inmisión en la existencia de un número creciente de trabajadores ${ }^{14}$.

Este tipo de técnicas pueden resultar lesivas, en determinados momentos y según los casos, para el derecho a la intimidad del trabajador.

II.2. Colisión de derechos con el poder empresarial en el centro de trabajo

Ningún Estado prohíbe en la actualidad, con carácter absoluto, el control electrónico en el puesto laboral, ni siquiera en aquellos países en los que está arraigada una fuerte cultura de protección de la intimidad. Por ello, el empleador ha pasado a controlar además de la actividad productiva, al propio trabajador. Ello impone por tanto una delimitación precisa del alcance de este poder de control del empleador ${ }^{15}$.

En términos generales, es difícil definir el poder de control empresarial en una relación de trabajo. La noción de control integra un conjunto diverso de actuaciones cuyo

\footnotetext{
I3 Rodriguez Copé, L., «El derecho a la intimidad del trabajador como límite al poder de dirección empresarial», Temas laborales, núm.62, 200I, pág. 2I6.

I4 Gude FernandeZ, A., «La videovigilancia laboral y el derecho a la protección de datos de carácter personal», Revista de Derecho político, núm.9I, 20I4, pág. 46.

I5 Ibidem, pág. 47.
} 
objetivo es la incidencia sobre una realidad, de conformidad con los fines legítimos perseguidos por quien tiene la facultad jurídica de realizar tal intervención ${ }^{\mathrm{I} 6}$.

Ahora bien, resulta complicado definir el propio concepto, y por ende, resulta igual de complicado delimitarlo de manera que no produzca una colisión con otros derechos.

Incluso, como dice SEGOVIANO ASTABURUAGA, «una vez finalizada la relación laboral, puede subsistir la intromisión del empresario en la esfera de la actividad del trabajador, como sucede en los supuestos en que se ha suscrito un 'pacto de no competencia', para después de extinguido el contrato de trabajo»" Aunque este pacto no puede tener una duración superior a dos años para los técnicos, y seis meses para los demás trabajadores, como establece el artículo 2I.2 del Real Decreto Legislativo I/I995, de 24 de marzo, por el que se aprueba el texto refundido del Estatuto de los Trabajadores (ET).

En general, en el ámbito del contrato de trabajo no se pone en duda que «el empresario, como acreedor de la prestación del servicio, debe tener derecho a controlar la ejecución de la actividad que lo integra» ${ }^{18}$. En el contrato de trabajo se encuentra el fundamento jurídico más inmediato del poder de dirección. El contrato es el título jurídico que legitima el ejercicio y la puesta en marcha de las facultades ordenadoras, como pueden ser las órdenes y las instrucciones, pero también de facultades de decisión, control y vigilancia propias de la organización empresarial ${ }^{\text {I9 }}$.

Ahora bien, como afirman SEMPERE NAVARRo y SAN MARTín MAZZUCONI, «la Constitución no puede quedarse a las puertas de los centros de trabajo, más en concreto, que los DDFF que la CE reconoce no pueden desaparecer o quedar suspendidos por el hecho de que exista una colisión laboral» ${ }^{20}$.

Así, podemos citar varios preceptos que se ocupan de defender dicho aspecto. El primer precepto es el art. I97 del Código Penal (CP), genérico para el derecho a la intimidad, ya que no opera únicamente en el ámbito laboral. Este artículo castiga al que sin el consentimiento de la otra parte, utilice artificios técnicos de escucha, transmisión, grabación o reproducción del sonido o de la imagen para descubrir los secretos o vulnerar la intimidad de otro, con penas de prisión de uno a cuatro años y multa de doce a veinticuatro meses.

De forma específica se encuentra el Real Decreto Legislativo 5/2000 de 4 de agosto, por el que se aprueba el Texto Refundido de la Ley sobre Infracciones y Sanciones en el orden social, configura como infracciones graves y muy graves, en materia de relaciones laborales individuales y colectivas, conductas que suponen vulneración de los derechos de

\footnotetext{
I6 MARTinez Fons, D., El poder de control del empresario en la relación laboral, Madrid, 2002, págs. I9-25.

I7 Segoviano Astaburuaga, L., «El difícil equilibrio entre el poder de dirección del empresario y los Derechos Fundamentales de los trabajadores», Revista jurídica de Castilla y León, núm.2, 2004, pág. I5I.

I8 MARTinez Fons, D., op. cit., pág. 25.

I9 MARTINEZ Fons, D., op. cit., págs. 26-39.

20 Sempere Navarro, A.V. y SAn Martin Mazzuconi, C., Nuevas tecnologías y relaciones laborales, Aranzadi, 2002, pág. 42
} 
libertad sindical (arts. 7 y 8), de huelga (art. 8), del derecho a la intimidad del trabajador (art. 8), y de la interdicción de discriminación (art. 8) ${ }^{2 \mathrm{I}}$.

Así mismo «el artículo 7 tipifica como infracción grave los actos u omisiones que fueren contrarios a los derechos de los trabajadores, reconocidos en el art. 4 ET, salvo que proceda su calificación como muy graves» ${ }^{22}$.

A partir de aquí surge el problema de la eventual colisión entre derechos del empresario y derechos de los trabajadores, ya que una actividad de inspección total por parte del empresario puede colisionar con los derechos de los empleados, en especial, como ya se ha dicho, con el derecho a la intimidad, el secreto de las comunicaciones, la libertad sindical, el derecho de huelga y la protección de datos.

El TC sostiene que la celebración del contrato de trabajo no implica la privación para una de las partes, en concreto el trabajador, de los derechos que la CE le reconoce como ciudadano, aunque el ejercicio de tales derechos en el seno de la organización productiva pueda admitir ciertas modulaciones o restricciones ${ }^{23}$. Estas deben estar fundadas en razones de necesidad estricta, debidamente justificadas por el empresario y sin que haya razón suficiente para excluir, a priori, que puedan producirse eventuales lesiones del derecho a la intimidad de los trabajadores en los lugares donde se realiza la actividad laboral propiamente dicha.

En definitiva, las empresas no pueden ser ajenas a los principios y derechos constitucionales que informan el sistema de relaciones de trabajo.

En esa línea, el TC defiende que las facultades empresariales solo pueden limitar este derecho si la propia naturaleza del trabajo contratado implica la restricción del mismo (STC 99/1994, FJ. 7 y STC 106/1996, FJ. 4). Esta puede venir por una acreditada necesidad o interés empresarial, sin que sea suficiente invocarlo para que sea legítimo el sacrificio del derecho fundamental del trabajador.

Una colisión de esta naturaleza viene reflejada en el art. 20.3 ET, que expone que «el empresario podrá adoptar las medidas que estime más oportunas de vigilancia y control para verificar el cumplimiento por el trabajador de sus obligaciones y deberes laborales, guardando en su adopción y aplicación la consideración debida a su dignidad humana y teniendo en cuenta la capacidad real de los trabajadores disminuidos, en su caso».

Unido a este artículo, se encuentra el art. 64.4 d) ET, que señala como una de las competencias del Comité de empresa la de emitir un informe con carácter previo a la ejecución por parte del empresario de las decisiones adoptadas por este sobre la implantación o revisión de sistemas de organización y control del trabajo.

El Estatuto de los Trabajadores otorga al empresario estas facultades pero limitadas por el artículo 4.2 e) ET. que defiende que «en la relación de trabajo, los trabajadores tienen derecho al respeto de su intimidad y a la consideración debida a su dignidad, comprendida la protección frente al acoso por razón de origen racial o étnico, religión o convicciones,

\footnotetext{
2I Segoviano Astaburuaga, L., op. cit., págs. I53-I54.

22 Ibidem, pág. I54.

23 STC 88/1985, de I4 de agosto, FJ. 2.
} 
discapacidad, edad $u$ orientación sexual, y frente al acoso sexual y al acoso por razón de sexo».

Por esto, el ejercicio de los derechos incluidos en ambos preceptos, únicamente admite limitaciones en la medida en que se desenvuelve en el seno de una organización, ya que esta se apoya en otros derechos constitucionales y fundamentales (arts. 33 y $38 \mathrm{CE})^{24}$ y que impone la necesaria adaptabilidad para el ejercicio de todos ellos 25 , perspectiva esta desde la que deben valorarse las específicas limitaciones que a los DDFF les pueda imponer el propio desarrollo de la relación laboral ${ }^{26}$.

Tras un primer acercamiento a estos dos preceptos, cabe decir siguiendo a DEL VALLE VILLAR que los límites impuestos a la actividad controladora del empresario implican que no puede inmiscuirse en cuestiones que excedan el cumplimiento de obligaciones de trabajo ${ }^{27}$.

Además, no puede utilizarse subordinados en la cadena jerárquica de la empresa para establecer un sistema de espionaje laboral, ni puede tolerar que este sistema se establezca por iniciativa de alguno de sus empleados. Esto puede conllevar, para el empresario, responsabilidades tanto administrativas como penales y, para el trabajador, el despido por quebrantamiento de la buena fe contractual, además de la posible responsabilidad penal.

Tampoco podrá contratar expresamente a personas con la finalidad de vigilar aspectos o actividades extracontractuales del trabajador.

No está así vetada la contratación laboral de personas que realice funciones de vigilancia y control en la empresa, si bien dicha vigilancia no puede incluir la intervención en problemas laborales o sociales que puedan surgir en el seno de la empresa donde presta sus servicios, ni se permite que asuman funciones de control sobre la vida privada de los trabajadores ${ }^{28}$.

Dado que los preceptos del ET mencionados no habilitan de manera expresa para la instalación y utilización de estos mecanismos de control y vigilancia consistentes en sistemas de captación de imágenes o grabación de sonidos dentro de los centros de trabajo, hay que acudir a la jurisprudencia del Tribunal Constitucional para conseguir delimitarlos.

El TC ha rechazado la premisa (de la que parte alguna sentencia recurrida) de que el centro de trabajo no constituye, por definición, un espacio en el que se ejerza el derecho a la intimidad por parte de los trabajadores, de tal forma que las conversaciones que mantengan

\footnotetext{
24El art. 33 CE defiende que «nadie podrá ser privado de sus bienes y derechos sino por causa justificada de utilidad pública o interés social, mediante la correspondiente indemnización y de conformidad con lo dispuesto por las leyes», mientras que el art. $38 \mathrm{CE}$, expone que «se reconoce la libertad de empresa en el marco de la economía de mercado. Los poderes públicos garantizan y protegen su ejercicio y la defensa de la productividad, de acuerdo con las exigencias de la economía general y, en su caso, de la planificación».

25 Tal y como explican las SSTC 99/ı994 de II de abril, FJ. 4, I06/ı996, de I2 de junio, FJ. 3, y I36/i996, de 23 de julio, FJ. 7 .

26 Según defienden las SSTC 99/I994, de iı de abril, FJ. 4 y 6/1995, de io de enero, FJ. 2.

27 Del Valle Villar, J., «El derecho a la intimidad del trabajador durante la relación de trabajo en el ordenamiento laboral español», Estudios sobre el derecho a la intimidad, I992, págs. I59-I60.

28 Del Valle Villar, J., op. cit., I992, págs. I67-I68.
} 
los trabajadores entre sí y con los clientes en el desempeño de su actividad laboral no siempre están amparados en el artículo I8 CE, según se expone en la STC I42/I993, de 22 de abril, FJ. $8^{29}$.

El Tribunal sigue diciendo que el derecho se ejercita en el ámbito de la esfera privada del trabajador, que en el caso del centro productivo hay que entenderlo limitado a los lugares de descanso o esparcimiento, vestuarios, lavabos o análogos, pero no incluye aquellos lugares en los que se desarrolla la actividad laboral en sentido estricto. Y ello porque el ET deja claro que está prohibida la instalación en estos lugares de medios de grabación de imágenes o escuchas y que se considerará lesiva en todo caso del derecho a la intimidad de los trabajadores.

Esto tiene que ser matizado, pues no cabe ignorar que, haciendo un análisis detallado y conjunto de esos hechos, es factible acceder a informaciones relativas a la vida íntima y familiar del trabajador que pueden resultar lesivas, en lugares del centro de trabajo que no sean esos espacios de descanso y esparcimiento de los que la Ley habla ${ }^{30}$.

El Tribunal ya ha aclarado que pueden producirse intromisiones ilegítimas por parte del empresario en el derecho a la intimidad de los trabajadores ${ }^{3 \mathrm{I}}$, como podría serlo la grabación de conversaciones entre un trabajador y un cliente o entre los propios trabajadores, en los que se aborden cuestiones ajenas a la relación laboral que se integran en lo denominado como propia esfera de desenvolvimiento del individuo ${ }^{32}$.

En definitiva, «el derecho a la intimidad penetra en la empresa y no lo hace limitándose a espacios concretos ajenos a la actividad laboral, sino que puede tener manifestaciones en lugares en los que se desarrolla dicha actividad, con motivo de la misma y durante el tiempo considerado como de trabajo»"

Lo que habrá que comprobar, según la STC 98/2000, es si la implantación del sistema de audición y grabación es conforme con los principios de proporcionalidad e intervención mínima que rigen la modulación de los DDFF por los requerimientos propios del interés de la organización ${ }^{34}$.

29 El recurso de inconstitucionalidad se dirigió contra varios preceptos de la Ley 2/I99I, de 7 de enero, sobre derechos de información de los representantes de los trabajadores en materia de contratación. El fundamento en cuestión trata sobre si se puede plasmar el salario y las retribuciones de los trabajadores en la copia simple del contrato de trabajo que se pone a disposición de los representantes de los trabajadores. Este defiende que «las retribuciones que el trabajador obtiene de su trabajo no pueden en principio desgajarse de la esfera de las relaciones sociales y profesionales que el trabajador desarrolla fuera de su ámbito personal e íntimo, para introducirse en este último, y hay que descartar que el conocimiento de la retribución percibida permita reconstruir la vida íntima de los trabajadores».

30 Rodriguez Coarasa, C., «Algunas proyecciones del Derecho Constitucional a la intimidad en el ámbito laboral», Revista de Derecho Político, núm.5I, 200I, pág. I89.

3I STC98/2000, de io de abril, FJ. 6.

32 STC 23I/I988, de 2 de diciembre, FJ. 4 y STC I97/I99I, de I7 de octubre, FJ. 3.

33 VALDÉs De LA VeGA, B., op. cit., pág. I45.

34 La Sentencia, promovida por el recurso de amparo 40I5/96, versa sobre un Casino que para conseguir un mayor control de la actividad laboral, que se desarrollaba en las instalaciones dedicadas al juego de azar y, en concreto, en las dependencias de caja y en el lugar donde se hallaba ubicada la ruleta francesa, decidió completar el sistema de seguridad que tenía, consistente en un circuito cerrado de televisión, con la instalación de unos micrófonos que recogían y grababan las conversaciones en esa zona del casino. 
Con respecto a los medios audiovisuales de control, la instalación de circuitos de cámaras de televisión en ocasiones está plenamente justificada por su naturaleza, en muchos casos por razones de seguridad, productivos o como prevención de robos. Así, «por razones de seguridad, su instalación es preceptiva, por ejemplo, en los bancos, cajas de ahorro y demás entidades de crédito, como medio de identificación de los autores de eventuales delitos contra las personas y contra la propiedad; por razones productivas, en aquellas empresas en las que los trabajadores desempeñen actividades que puedan resultar peligrosas y por último, como medida preventiva, en centros comerciales, al ser un medio disuasorio de comisión de hurtos y de identificación de los mismos» ${ }^{35}$.

En cuanto a los medios auditivos, la instalación de micrófonos que permiten interceptar escuchas y grabar conversaciones es difícilmente justificable por razones de seguridad en la empresa, lo cual apoya la afirmación de que suponen un atentado contra el derecho a la intimidad y al derecho al secreto de comunicaciones de los trabajadores ${ }^{36}$.

Como bien dice GUDE FERNÁNDEZ la jurisprudencia ha calificado la grabación de una conversación en líneas generales como más atentatoria con el derecho a la intimidad que la de una imagen (al margen de que la captación de ésta haga entrar en juego también el derecho fundamental a la propia imagen), sobre la base de que la grabación de una conversación puede revelar pensamientos y sentimientos internos que la mera captación de imágenes en principio no proporcionaría ${ }^{37}$.

No obstante, la jurisprudencia ha ido evolucionando en lo que a escuchas telefónicas se refiere.

La STS de io de marzo de I990 se pronunció sin matices, al declarar nula radical cualquier escucha telefónica, dado que, siguiendo la doctrina del TC, de la CE se deriva la prohibición de la interceptación o del conocimiento antijurídico de las comunicaciones ajenas o, lo que es lo mismo, la prohibición de la escucha de la conversación telefónica por tercero ajeno a la comunicación misma.

La evolución de este criterio se ha ido produciendo hasta concluir que hay que analizar en cada caso concreto ciertos factores como es si el teléfono y la utilización del mismo forman parte de los instrumentos a través de los que se realiza la prestación de trabajo, si el empresario no es un tercero ajeno con respecto a la conversación que pueda mantener el trabajador sino todo lo contrario o cuándo se produce la escucha, si es por ejemplo, en un descanso interjornada o no ${ }^{38}$.

La sentencia concluye concediendo el amparo y reconociendo el derecho a la intimidad del trabajador, por no entender que la implantación del sistema de escucha no respeta los principios de proporcionalidad e intervención mínima, pues la finalidad que se persigue resulta desproporcionada para el sacrificio que implica al derecho a la intimidad de los trabajadores.

35 Rodriguez CoARASA, C., op. cit., págs. I9I-I92.

36 Ibidem., pág. I92. Se pueden citar por ejemplo, las cajas negras de los aviones que permiten registrar las conversaciones de los pilotos, cuya finalidad es la averiguación de las causas en caso de accidente

37 Gude FERnANDEZ, A., «La videovigilancia en el ámbito laboral y el derecho a la intimidad» Revista General de Derecho Constitucional, núm.20, 2015, pág. I3. En este sentido, véase también la STSJ Cataluña, de 25 de abril de I994, FJ.3.

38 Del Valle Villar, J., op. cit., pág. i68. 
Por esto, la STS de 5 de diciembre de 2003, analiza de nuevo la dialéctica y las tensiones existentes entre la garantía de los derechos básicos del trabajador y las facultades de control empresariales.

El Sindicato Unión Telefónica Sindical (UTS) solicitó que se declarase la ilegalidad de las escuchas practicadas por la empresa respecto de las llamadas efectuadas desde el servicio telefónico I004, ya que entendía que afectaban al derecho a la intimidad de los trabajadores. La demanda fue desestimada por la Audiencia Nacional, ya que se consideró que esas escuchas tenían la finalidad de controlar el servicio prestado por la referida línea.

El recurso ante la Sala del TS se desestima porque consideran que supera el triple juicio de idoneidad, necesidad y proporcionalidad estricta que era el argumento en el que se apoyaba dicho recurso.

El TS concluye que «el teléfono controlado era una herramienta de trabajo para los teleoperadores que realizan esas funciones de telemarketing que solo controlan las entradas y no las salidas, de manera aleatoria y en un $0,5 \%$ de los casos, con la finalidad de mejorar el servicio y corregir las deficiencias incluso mediante acciones formativas, y habida cuenta de que, además, los afectados disponen de otro aparato para sus comunicaciones personales» ${ }^{39}$.

Dado que de lo hasta ahora explicitado por el TC no cabe deducir criterios de carácter general, todo indica que las condiciones y circunstancias de cada caso serán especialmente determinantes de la licitud de la inmisión por parte del empresario. Y de entre todas ellas, merecen especial atención las siguientes:

- Lugar del centro de trabajo en el que se instalan los sistemas.

- Si la instalación se hace o no indiscriminada y masivamente.

- Si los sistemas son visibles o han sido instalados subrepticiamente.

- Finalidad real perseguida con la instalación de tales sistemas.

- Si existen razones de seguridad suficientes.

- Tipo de actividad que se desarrolla en el centro de trabajo de que se trate.

- Razones que abonan a favor de la implantación de tales medios de control ${ }^{40}$.

39 Gabinete Técnico del Tribunal Supremo, «Crónica de Jurisprudencia», Sala $4^{a}$ del Tribunal Supremo (2003-2004).

40 Sobre esto, la STSJ de Madrid 739/20I4, de 29 de septiembre, no permite la colocación de dispositivos de localización GPS en el vehículo de empresa cedido a una trabajadora, pues no es el lugar de trabajo adecuado para la colocación. En la misma línea, el auto del TS de 23 de noviembre, considera ilícita la colocación de cámaras debajo de la mesa de los trabajadores.

La STSJ de Madrid I65/20I2, de I2 de marzo, considera nulo un despido por una prueba ilícita de grabación de imágenes de unas cámaras instaladas masiva y discriminadamente.

La STSJ de Extremadura 274/20II, de I4 de junio, que declara un despido procedente por el uso del ordenador para fines particulares, donde el empleado sabía de su prohibición y de la instalación de medidas de seguridad para su control, por lo que no habían sido instaladas subrepticiamente.

La STSJ de Galicia 5859/20Io, de I7 de diciembre, reconoce como procedente unos reconocimientos médicos obligatorios, ya que los trabajadores se exponen a agentes químicos peligrosos. Lo avala explicando que existen razones de seguridad suficientes por el tipo de actividad que se desarrolla y la finalidad real perseguida por la empresa es evitar enfermedades profesionales. 
Se tratará además, de comprobar en cada caso concreto si los medios de vigilancia y control respetan el derecho a la intimidad de los trabajadores, procediendo a una ponderación adecuada que garantice la correcta definición y valoración constitucional del derecho fundamental en juego y de las obligaciones laborales que pueden modularlo en la medida imprescindible para el desenvolvimiento de la actividad productiva.

En conclusión, los equilibrios y limitaciones recíprocos que se derivan para ambas partes del contrato de trabajo suponen que también las facultades organizativas empresariales se encuentran limitados por los DDFF del trabajador, quedando obligado el empleador a respetar aquellos ${ }^{4 \mathrm{I}}$.

A esta lista de características a tener en cuenta a la hora de decidir si hay una intromisión en la esfera privada del trabajador, hay que añadir la diligencia del trabajador a la hora de defender sus derechos ${ }^{42}$.

En este sentido, la sentencia del TSJ de Asturias, de I7 de noviembre de 2000, no considera vulnerado el derecho a la intimidad de una trabajadora del hospital que, estando de baja por enfermedad, recibió una carta para que retirase sus efectos personales de la taquilla, por una reasignación del personal, invitándola a recoger la llave de su nueva taquilla situada en otra localización del hospital.

El Tribunal concluye que, a la hora de defender sus derechos, si el trabajador opta por la pasividad ante una comunicación de la empresa de que realice una acción que, si realiza la propia empresa, podría resultar lesiva de su derecho a la intimidad, se está demostrando un desinterés en la salvaguarda de su esfera personal, por lo que ratificaría la constitucionalidad de la acción empresarial sustitutiva de su inacción.

Al ser los órganos jurisdiccionales los encargados de decidir en cada caso concreto, atendidas todas estas circunstancias mencionadas, serán ellos los que concluirán si la medida restrictiva del derecho a la intimidad supera el juicio de proporcionalidad, cuyo contenido ha venido reiterando el TC.

Para poder superar este test, será necesario constatar que la medida cumple con tres requisitos recogidos en la STC 89/2006, de 27 de marzo, a saber:

- que la medida sea susceptible de conseguir el objetivo propuesto, denominado como juicio de idoneidad, lo que obliga a desechar aquellas vías que, basándose en consideraciones fácticas, no sean idóneas para conseguir la finalidad perseguida;

- que la medida sea necesaria, en el sentido de que no exista otra medida más moderada para la consecución de ese propósito con igual eficacia, por lo que la necesidad de la medida limitadora implica constatar que la restricción del Derecho Fundamental sea estrictamente indispensable o imprescindible para la salvaguarda de la facultad que ha legitimado su adopción, definido como juicio de necesidad;

- que la medida sea ponderada o equilibrada por derivarse de ella más beneficios o ventajas para el interés general que perjuicios sobre otros bienes o valores en conflicto,

4I STC 292/I993, de I8 de octubre, FJ. 4.

42 Rodriguez Copé, L., op. cit., págs. 224-226. 
denominado como juicio de proporcionalidad, en sentido estricto ${ }^{43}$. El criterio exige llevar a cabo una ponderación entre la intensidad de la intervención del Derecho Fundamental y el peso de las razones que la justifican.

\section{II.3. Colisión de derechos con el poder empresarial fuera del centro de trabajo}

La colisión de derechos en el ámbito laboral no se limita a la actividad del trabajador dentro de una empresa. El problema se puede acentuar cuando se refiere a los controles empresariales ajenos a la causa contractual, como pueden ser los registros sobre la persona física del trabajador, sus taquillas, sus efectos particulares o sobre los comportamientos extralaborales del trabajador.

La doctrina científica se ha planteado, concretamente, si el empresario puede con fines disciplinarios confiar a agentes investigadores la tarea de vigilancia de los trabajadores y si es admisible que el empresario utilice los servicios de una agencia de investigación privada para averiguar si los empleados cometen actos lesivos contra la actividad empresarial o contra el patrimonio de la empresa.

Aquí podemos afirmar que se produce o puede producirse una confrontación entre el artículo 4.2 ET y el artículo I8 CE, en colisión con el artículo 20.3 ET, visto con anterioridad.

La aplicación práctica del conflicto con estos derechos adquiere importancia en las situaciones de absentismo por enfermedad del trabajador, donde el empresario, apoyándose en el artículo 20.3 ET, trata de extender su facultad más allá del concreto ámbito donde se desenvuelve la prestación de trabajo, bajo el pretexto de controlar aquellas actividades que, aun realizándose fuera del centro de trabajo y al margen de la relación laboral, pueden afectar de manera directa al desenvolvimiento de la relación laboral ${ }^{44}$.

Como regla general, únicamente se permite hacer el acceso legítimo a la esfera privada de cualquier trabajador mediante el interés público y mediante el consentimiento del titular ${ }^{45}$. Por lo que parte de la doctrina considera, criterio que compartimos, que el art. 20.3 ET no podría servir como base de justificación de la injerencia del empresario en la vida extralaboral del trabajador. Sobre todo, porque el ET ya hace una previsión, legitimando al empresario de forma expresa para controlar las ausencias al trabajo del trabajador por causa de enfermedad o accidente. El artículo 20.4 ET establece un mecanismo de control excepcional, cuando expone que «el empresario podrá verificar el estado de enfermedad o accidente del trabajador que sea alegado por este para justificar sus faltas de asistencia al trabajo, mediante reconocimiento a cargo de personal médico».

Por lo que cabe afirmar que, en este caso concreto, el legislador admite la intromisión en la vida privada del trabajador cuando se produce una ausencia por enfermedad. No obstante, en el artículo se establecen dos significativos límites: uno de

\footnotetext{
43 SSTC 89/2006, de 27 de marzo, FJ. 3, I4/2003, de 28 de enero, FJ. 9, y 89/2006, de 27 de marzo, FJ. 3.

44 RodRIGUEZ Copé, L., op. cit., págs. 2I9-220.

45 Ibidem, pág. 22I.
} 
fondo, pues solo cabe realizar actuaciones dirigidas a comprobar el estado de incapacidad, y otro de forma, pues especifica que solo se podrá llevar a cabo por personal médico.

Además, a los derechos del empresario derivados del ET que permiten verificar como ya se ha dicho, el estado de enfermedad o accidente del trabajador que motiva la inasistencia al trabajo, a través de personal médico, que se supone de la confianza del empresario, la Ley añade un refuerzo mediante la sanción de trabajadores que no consientan en someterse a esta verificación.

Por ello, la negativa del trabajador puede conllevar «la suspensión de los derechos económicos que pudieran existir a cargo del empresario por dichas situaciones, o de las mejoras voluntarias pactadas en los convenios o acuerdos colectivos, o bien en el propio contrato de trabajo, aunque este último no ha sido suficientemente valorado por la doctrina» ${ }^{46}$.

A pesar de esto, hace décadas que los Tribunales admiten como práctica normal la validez de los hechos basados en informes de detectives privados que investigan por cuenta y cargo de la empresa.

Como ejemplo claro de este aspecto, hay que citar la Sentencia del TSJ de la Comunidad Valenciana de 3 de febrero de 2000. En la Sentencia se deja claro que la grabación mediante vídeo de un trabajador que se encontraba de baja por una situación de incapacidad temporal, por un diagnóstico médico de psicosis afectiva, es válida, pues no vulnera el derecho a la intimidad.

Esto es así, porque la Ley 5/2004, de 4 de abril, de Seguridad Privada permite este tipo de intromisiones ${ }^{47}$.

Entendemos por tanto, que la instauración de un generalizado régimen de espionaje no es tolerable, pero, por otra parte, parece ilógico excluir de plano todo tipo de vigilancia sobre un trabajador en concreto, porque no parece aceptable que el ciudadano pueda verse sometido a observación en la calle por detectives contratados por cualquier particular y, en cambio, se prohíba todo tipo de vigilancia por el hecho de que sea el empresario el que se encargue de la misma ${ }^{48}$.

Por lo que consideramos que la contratación de un detective para controlar la actividad del trabajador podría ser lícita en la medida en la que haya sospechas fundadas,

\footnotetext{
$4^{6}$ Del Valle Villar, J., op. cit., pág. I74.
}

47 La Ley 5/20I4, de 4 de abril, de Seguridad Privada, tiene por objeto regular la realización y la prestación por personas privadas, de actividades o servicios de seguridad privada que son contratados por personas físicas o jurídicas, públicas o privadas para la protección de personas o bienes.

El art.Io.I.d) de esta Ley prohíbe el empleo o utilización, en servicios de seguridad privada, de medidas o medios personales, materiales o técnicos que atenten contra el derecho al honor, a la intimidad personal o familiar o a la propia imagen o al secreto de las comunicaciones.

En cuanto al uso de los sistemas, el art.42.4 especifica que las grabaciones realizadas por los sistemas de videovigilancia no podrán destinarse a un uso distinto del de su finalidad. Cuando las mismas se encuentren relacionadas con hechos delictivos o que afecten a la seguridad ciudadana, se aportarán, de propia iniciativa o a su requerimiento, a las Fuerzas y Cuerpos de Seguridad competentes, respetando los criterios de conservación y custodia de las mismas para su válida aportación como evidencia o prueba en investigaciones policiales o judiciales.

$4^{8}$ Del Valle Villar, J., op. cit., pág. I70. 
concretas y motivadas, pero sin permitir al empresario abusar de este tipo de acciones, que los tribunales aceptan cada vez con más facilidad y que limitan demasiado con las tácticas abusivas, para las que ya hay opciones legales, como el art. 20.4 ET.

\section{II.4. Problemática del empleo de los medios de control por parte de la empresa}

En este punto, partiendo de la premisa de que existe justificación para la instalación de medios de control en un centro de trabajo determinado, hay que hacer un estudio de la utilización de los datos o resultados que arroje dicha instalación.

Es claro que la posibilidad de utilizar estos datos no es indicativo de que quepa hacer un uso indiscriminado de ellos, de tal forma que se pueda lesionar la dignidad e intimidad del trabajador, por lo que habrá que observar si pueden llegar a concurrir intereses ilegítimos, donde recabar información sobre los comportamientos y hábitos de los trabajadores sea la intención empresarial o incluso sea la de ejercer una mayor presión en la conducta de estos trabajadores mediante un control intensivo.

La garantía en tales casos de que el material recogido no se va a utilizar para fundar una sanción contra el trabajador, no puede ser otra que la buena fe contractual tanto del empresario como del trabajador, unida a la exigencia de un uso coherente de los medios audiovisuales de acuerdo con la causa y la finalidad que llevó a su instalación ${ }^{49}$.

Esta buena fe contractual viene impuesta en el Estatuto de los Trabajadores, concretamente en el artículo 20.2 donde estipula que «en el cumplimiento de la obligación de trabajar asumida en el contrato, el trabajador debe al empresario la diligencia y la colaboración en el trabajo que marquen las disposiciones legales, los convenios colectivos y las órdenes o instrucciones adoptadas por aquel, en el ejercicio regular de sus facultades de dirección y, en su defecto, por los usos y costumbres. En cualquier caso, el trabajador y el empresario se someterán en sus prestaciones recíprocas a las exigencias de la buena fe».

No obstante, aunque de forma general no es admisible la imposición de medidas disciplinarias por infracciones cometidas por los trabajadores como consecuencia de la observación de la empresa a través de estos medios, no se excluye la posibilidad de que la empresa adopte las medidas necesarias para la averiguación de todas aquellas circunstancias que puedan redundar en perjuicio de su desarrollo, siempre que, claro está, se ajuste a los límites establecidos ${ }^{50}$.

Hay que destacar aquí que es distinto que las medidas de control hayan sido instaladas por motivos de seguridad, por la actividad que realiza la empresa, o que hayan sido colocadas de manera oculta para investigar a algún trabajador del que existan fundadas sospechas de que está realizando alguna actividad sancionable o que vulnera la buena fe contractual.

Hay multitud de sentencias que avalan esta premisa. Entre ellas la STSJ de La Rioja núm. 379/2000 de 5 diciembre de 2000 , donde el trabajador considera vulnerado su

\footnotetext{
49 Martin Jimenez, R., «El derecho a la intimidad del trabajador y las cámaras de vigilancia», Diario de las Audiencias y TSJ El Derecho, núm.29I, 2002, pág. 3.

50 Ibidem.
} 
derecho a la intimidad por el hecho de filmar cómo desempeñaba su trabajo, al haberse detectado por la empresa irregularidades en su actuación laboral.

El Tribunal concluye el caso dictando que la medida de instalación del circuito cerrado de televisión era una medida justificada (ya que existían razonables sospechas de la comisión por parte del recurrente de graves irregularidades en su puesto de trabajo); idónea para la finalidad pretendida (verificar si el trabajador cometía efectivamente las irregularidades sospechadas para adoptar las medidas disciplinarias correspondientes); necesaria (ya que la grabación serviría de prueba de las irregularidades); y equilibrada (pues la grabación de imágenes se limitó a la zona de la caja y a una duración temporal limitada, la suficiente para comprobar que no se trataba de un hecho aislado o una confusión, sino de una conducta ilícita reiterada), por lo que descarta que se haya producido una lesión del derecho a la intimidad.

Otro caso semejante recoge la STC i86/2000 de io julio. El recurrente considera vulnerado su derecho a la intimidad por la instalación, por parte de su empresa, de un circuito cerrado de televisión colocado en su puesto de trabajo (la caja registradora y el mostrador), que la empresa había contratado como vigilancia tras advertir un proceder irregular y un descuadre en la caja. El TC no considera vulnerado ese derecho pues se cumple el juicio de proporcionalidad, al ser una medida justificada, idónea, necesaria y equilibrada.

El Repertorio de Recomendaciones Prácticas de la Organización Internacional del Trabajo (OIT) únicamente acepta la videovigilancia oculta, si así se reconoce por ciertas disposiciones de la legislación nacional o si existen sospechas suficientes de actividades delictivas o infracciones graves en el ámbito de control de la empresa.

España sigue esta praxis de aplicación permitiendo este tipo de actuaciones, pero moduladas mediante la jurisprudencia. Se permite esta práctica en casos excepcionales como los ejemplos anteriores, pero se ponderará también que la grabación sirva de prueba a las actuaciones, que los mecanismos de control se limiten a la zona de los hechos, que sea durante un periodo temporal determinado (el suficiente para constatar lo sucedido), que no haya persecución visual del actor, ni de sus actos..., para que no se entienda vulnerado su derecho a la intimidad ${ }^{5 \mathrm{I}}$.

En cualquier caso, el aparato no constituye más que un medio de prueba válido de los varios que puede tener en cuenta el juez, como elemento de convicción con la finalidad de valorar la existencia o inexistencia de conducta sancionable.

Hay que hacer especial mención al caso de las llamadas telefónicas en la empresa. Con base en el derecho a la intimidad y reforzado por el derecho al secreto de las comunicaciones, se deberán reputar como ilícitas todas las escuchas clandestinas realizadas por el empresario sobre conversaciones del trabajador, siendo indiferente que estas un contenido privado o no. Por ello, los secretos descubiertos ilícitamente no pueden ser utilizados en un proceso, tal como hemos mencionado antes, dado que no es admisible la prueba ilícitamente obtenida ${ }^{52}$.

5I Gude Fernandez, A., «La videovigilancia en el ámbito laboral y...», cit., págs. 23-24.

52 Rodriguez CoARASA, C., op. cit., pág. 2I5.

REDUR I3 / 2015 
Aun así, hay procedimientos de control que el empresario puede utilizar con la finalidad de evitar su uso abusivo por parte de los trabajadores. Concretamente nos referimos aquí a las centralitas telefónicas cuyo sistema informático que permite registrar el número de teléfono que efectúa la llamada, la duración de la misma, el número al que va dirigida, o el día y la hora en que se realiza ${ }^{53}$.

Por esto, no nos mostramos contrarios al control de la actividad laboral mediante aparatos mecánicos, e incluso por medios audiovisuales o informáticos y del uso controlado de los mismos. No obstante, parte de la doctrina considera, criterio que compartimos, que el uso de estos medios sí debería de alguna manera ser a su vez objeto de control por los trabajadores, como individuos controlados que son, a través de sus representantes ${ }^{54}$.

\section{El derecho a la intimidad y los avances informáticos}

Como ya se ha mencionado anteriormente, el desarrollo informático arrastra la aparición de serios peligros para la intimidad del ciudadano en general, y del trabajador en particular, porque permite el conocimiento, almacenamiento y tratamiento de infinidad de datos de una persona, que ignora que están siendo controlados, facilitando asimismo el conocimiento de comportamientos, aficiones, creencias religiosas, orientación sexual...

Como afirma Segoviano Astaburuaga «este desarrollo del mundo cibernético representa un peligro más para la intimidad, viéndose desbordadas sus formas clásicas de protección jurídica por estas nuevas tecnologías en continuo avance» ${ }^{55}$.

Esto hace que se empiece a hablar de libertades de tercera generación, dada la evolución del derecho a la intimidad con las tecnologías de la información y de la comunicación (TIC).

El uso de las TIC por los trabajadores en el puesto de trabajo se entiende como la labor «que se lleva a cabo por el trabajador utilizando los medios informáticos proporcionados por el empleador con el exclusivo fin de desarrollar las tareas propias de la relación laboral» ${ }^{56}$. De esto se desprende que el uso de estas nuevas tecnologías presenta tres dimensiones: espacial, temporal y finalista.

La dimensión espacial se refiere a que puede llevarse a cabo en los locales de la empresa o fuera de ellos, por ejemplo, con un ordenador portátil entregado por el empresario. Una dimensión temporal, pues ese uso puede realizarse dentro de la jornada de trabajo o fuera de ella. También existe una dimensión finalista o teleológica, en la medida en que el uso de las nuevas tecnologías puede producirse en desarrollo de las tareas propias de la relación laboral o para un fin exclusivamente particular del trabajador ${ }^{57}$.

53 Ibidem, pág. 216.

54 Del Valle Villar, J., op.cit., pág. I74. En este sentido, por ejemplo, en Italia la instalación de este tipo de aparatos requiere del acuerdo con los representantes de los trabajadores, o en su defecto, autorización administrativa.

55 Segoviano Astaburuaga, L., op. cit., pág. 156.

56 Ortiz De Solórzano Aurusa, C., «Facultades empresariales de control, TICs y privacidad del trabajador», Revista Aranzadi de Derecho y Nuevas Tecnologías, núm.37, 2015, pág. 3.

57 Ibidem. 
Por lo que se puede afirmar, con GonZÁlez DEL OlMo que dos son los problemas principales que han generado el uso de internet y el correo electrónico en el ámbito laboral: la legalidad de dicho uso para fines no empresariales por parte de los empleados y la legalidad de los medios de control y revisión del correo electrónico de los trabajadores como remitentes o destinatarios del mismo ${ }^{58}$.

En la misma línea, emerge el derecho del empresario a controlar el medio de trabajo por él facilitado y el uso que los trabajadores hacen del mismo, cuestionándose si el poder del empresario abarca el control absoluto e ilimitado de dichos medios o existe alguna frontera que el empresario no pueda traspasar.

La tercera cuestión, por lo tanto, es la referente a la posibilidad de que el empresario realice un control absoluto que, sin ser necesariamente permanente, sea selectivo ante situaciones en las que, por el riesgo existente en un bien jurídico protegido, sea justificada la intromisión del empresario en el medio utilizado por el trabajador.

Esto ocurre porque las empresas advierten que los trabajadores pueden utilizar la infraestructura informática incorporada con cargo a la empresa, para disponer de ordenador, conexión a Internet y correo electrónico por diversos motivos ajenos a la actividad productiva ${ }^{59}$.

Ello conlleva un coste tanto económico como de imagen para la empresa. Sin olvidar el coste de servicio que supone que los trabajadores inviertan parte de su tiempo y dedicación al uso privado del correo electrónico, que por lo demás puede ser el corporativo de la empresa con su nombre comercial entre otros datos. Hay que tener en cuenta también los posibles daños que se puede causar a la infraestructura informática, tanto por el uso privado de la misma como por la entrada de virus no deseados, por ejemplo .

En cuanto a la vulneración del derecho a la intimidad, hay que poner de relieve, como ya venimos defendiendo, la necesidad de mantener un delicado equilibrio entre el derecho fundamental del trabajador a la intimidad y las facultades organizativas empresariales, entre las que se encuentra la vigilancia del trabajador.

De todas formas, algunas empresas amparándose en los artículos del ET que otorgan derechos de control y vigilancia al empresario, incluyen en los contratos de trabajo firmados con sus trabajadores, una cláusula en la que estos expresamente autorizan la injerencia de la empresa en su ámbito de intimidad laboral (acceso al correo electrónico, historial de navegación en Internet, instalación de cámaras de vigilancia,...).

Con todo cabe subrayar con Segoviano Astaburuaga que este tipo de autorizaciones no permite al empresario una intromisión indiscriminada en la esfera de la intimidad del trabajador.

Como apunta el referido autor, en primer lugar, hay que tener presente la dudosa validez del consentimiento prestado por el trabajador al firmar dicha cláusula del contrato de trabajo, pues generalmente no aparece como una cláusula libremente pactada por el

\footnotetext{
$5^{8}$ GonZalez Del Olmo, J., «Intimidad en el tráfico de las comunicaciones», Diario de las Audiencias y TSJ, núm.344, Madrid, 2003, pág. I.

59 Ibidem, pág. 2.

60 Ibidem.
} 
trabajador y el empresario, sino impuesta por este último, que es, en definitiva, el que ha redactado el contrato, al que el trabajador no hace sino adherirse.

En segundo lugar, el artículo 3.5 ET establece que «los trabajadores no podrán disponer válidamente antes o después de su adquisición de los derechos que tengan reconocidos por disposiciones legales de derecho necesario», por lo que, no se podría aceptar que el trabajador pueda renunciar al mismo mientras dure su relación laboral, menos aún de forma tácita, sobre la base del conocimiento y no oposición del trabajador de los medios de control empleados por el empresario. ${ }^{61}$.

Por lo tanto, exista o no consentimiento del empleado, e independientemente de que este sea expreso o tácito, al final la injerencia empresarial en el derecho a la intimidad debe confrontarse en cada caso con el reiterado juicio de proporcionalidad.

La jurisprudencia se ha pronunciado sobre este tema y se puede ver una evolución que se ha dividido en tres partes para su mejor comprensión.

En un primer momento, se parte del concepto de la titularidad tanto del correo electrónico, como de los canales de comunicación y equipos informáticos utilizados por el trabajador en sus comunicaciones privadas.

En la STSJ de Madrid, de I6 de octubre de I998, se admitió como conforme a derecho el registro del servidor proxy a través del cual se conectaba la empresa a la red con la finalidad de verificar el acceso con fines privados por parte de un empleado.

En la STSJ de Madrid, de I4 de noviembre de 2000 , conocido como el caso Deutsche Bank, directamente no se entra a valorar la legalidad del control por la empresa de las cuentas de correo electrónico y de internet de los trabajadores, sino que se da prácticamente por supuesto.

En ambas sentencias los tribunales españoles del orden laboral han admitido la procedencia de un despido del trabajador como consecuencia de un uso inadecuado de las infraestructuras electrónicas puestas al servicio de los trabajadores, calificándolo como violación de la buena fe contractual.

La STSJ de Cataluña, de 5 de julio de 2000 , apunta una conclusión importante y determinante sobre esta materia, ya que explica que no nos encontramos en presencia de una correspondencia privada entre particulares (el caso versa sobre el correo electrónico concretamente), sino ante una utilización indebida de medios que son de propiedad de la empresa, así como la propia actividad laboral del trabajador.

Con base en esta conclusión, las comunicaciones a través de estos medios no se encontrarían protegidas por el derecho a la intimidad, si bien los mismos tribunales han observado alguna limitación de las posibilidades de control de las empresas sobre los medios informáticos utilizados por sus trabajadores ${ }^{62}$.

Según estas primeras sentencias sobre el tema, este criterio de propiedad de la empresa y ajenidad del trabajador es obligado. Dado que la empresa era propietaria de los

\footnotetext{
6i Segoviano Astaburuaga, L., op. cit., págs. i6o-i6i.

62 GonZalez Del Olmo, J., op. cit., pág. 2.
} 
equipos informáticos y del canal de comunicación (en los casos en los que se disponga de intranet), se concluía que esta tenía derecho a acceder a su propio correo electrónico.

Para GonZÁlez Del Olmo, al que seguimos en lo que sigue, estas tecnologías (correo electrónico, equipo informático y línea telefónica) se consideran herramientas que la empresa pone al servicio del trabajador, para que desarrolle el trabajo para el que fue contratado en las mejores condiciones.

Por tanto, al trabajador, en principio, no le estaría permitido hacer uso del correo, ni de los medios electrónicos fuera de lo que constituye el interés de la propia empresa y de su actividad, y no podría utilizar el correo electrónico de la empresa para asuntos propios, con base en este criterio ${ }^{63}$.

Es claro que a la empresa le interesa que el correo se encuentre a su disposición y a su servicio, ya que, como expone GONZÁlEZ DEL OlMO, el no permitir este acceso al correo utilizado por el trabajador, conllevaría la incongruencia de no poder la empresa, como titular del medio, abrir el correo de un trabajador que se encuentre de baja, y, por ejemplo, atender los pedidos que ese trabajador recibe y debe contestar esos días.

Por este criterio de propiedad, la doctrina consideraba que no servían los razonamientos que intentan, mediante el recurso de la analogía, la protección que se otorga al correo físico, por la equiparación del uso del correo con una carta remitida al trabajador, porque el planteamiento base es erróneo.

«Si la empresa puede acceder a su propio correo electrónico también puede abrir una carta que manifiestamente va dirigida a ella (aunque vaya a nombre del trabajador), y de cuyo aspecto externo se deduzca que su contenido entra dentro del ámbito de la actividad empresarial» ${ }^{64}$.

El mismo autor, sostiene que tampoco serviría la equiparación con la protección que el derecho ofrece a las comunicaciones habladas (telefonía o grabaciones), ya que «en estas existe un plus en el que las expresiones usadas, la modulación de la voz, las inflexiones de la entonación e incluso los defectos del habla... tienen que ser protegidas por sus características eminentemente personales». El correo electrónico, sin embargo, al tratarse de un texto inanimado no cabría dentro de esta protección.

No se podría plantear esta cuestión en el caso de vulneración de la privacidad por el motivo ya expuesto anteriormente: el único titular del derecho a la privacidad del correo electrónico es la empresa, como propietaria del medio.

En consonancia con esto, no tendría sentido aplicar a los ordenadores y el correo electrónico la protección que se ha conferido a los trabajadores en cuanto a los registros realizados en el centro, en primer lugar porque estos registros están condicionados a la protección del patrimonio empresarial, y esta protección se acreditaría con el interés normal de la empresa en conocer el contenido de sus comunicaciones y de proteger su patrimonio.

63 Ibidem, pág. 4.

64 Ibidem, pág. 2. 
Y en segundo lugar, no se podría equiparar el correo electrónico a la taquilla del trabajador ya que esta supone el reconocimiento de un ámbito de privacidad del trabajador por parte de la empresa ${ }^{65}$.

Tras estos primeros criterios jurisprudenciales y doctrinales se ha ido evolucionando en la materia, si bien no se ha modificado la opinión de que no puede existir la opción de la analogía con el correo tradicional, las conversaciones habladas y, sobre todo, la aplicación del art. I8 ET a estas situaciones, como si de registros de taquillas se tratara.

En un segundo momento, la realidad social ha ido poniendo de manifiesto que en las empresas está ampliamente generalizado el uso privativo por los trabajadores, uso que suele ser tolerado por el empresario siempre que sea razonable y no constituya un abuso. Esta tolerancia empresarial situaría el debate no tanto en la posibilidad o imposibilidad del uso particular, sino más bien en los límites del uso privativo de las tecnologías de la empresa y el control empresarial del uso que hacen de ellas los trabajadores ${ }^{66}$.

Dado que no hay una regulación específica para esto, ni por tanto unas sanciones previstas, ni se incluyen estas causas en las causas legales de despido reguladas en el art. 54.2 ET, los conflictos derivados de la utilización de los trabajadores de los medios informáticos del empresario se resuelven por la vía de la trasgresión de la buena fe contractual.

Poner de relieva que un incumplimiento de este tipo debe producir un daño efectivo a la empresa y debe ser grave y culpable, es decir, intencionado. Por lo que no sería causa de despido el acceso puntual a internet para fines propios o la remisión de un solo correo electrónico.

Si bien es cierto que la jurisprudencia reconoció en su momento la procedencia del despido por un uso privado de las instalaciones, en forma de conexiones a internet ajenas a la actividad laboral, (STSJ Castilla y León, de 29 de enero de 200I), la instalación de ciertos programas informáticos o la introducción de datos ajenos a la actividad laboral por parte del trabajador en el ordenador de la empresa (STSJ Galicia, de 5 de junio de 2006) y el envío masivo de correos electrónicos con contenidos humorísticos en horas de trabajo (STSJ Cataluña, de I4 de noviembre de 2000) ${ }^{67}$.

Por esto, el sancionar o no la conducta del trabajador dependerá de la existencia de una política empresarial clara conocida por los trabajadores, sobre la tolerancia de la empresa a estos efectos.

En la evolución de esta jurisprudencia, tampoco se olvida que el ordenador es un instrumento de trabajo del que es titular el empresario, por lo que se reconoce que éste tiene facultades de control sobre su utilización para verificar su correcta utilización.

No obstante, tanto el TS como el TC reconocen que aunque los medios informáticos utilizados por el trabajador en una determinada comunicación pertenezcan al empresario,

\footnotetext{
65 Ibidem, pág. 3 .

66 Ortiz De SolóRzAno Aurusa, C., «Facultades empresariales de control, TICs y privacidad del trabajador», Revista Aranzadi de Derecho y Nuevas Tecnologías, núm.37, 2015, pág. 3.

67 Ibidem, pág. 4.
} 
el trabajador puede oponer su derecho al secreto de las comunicaciones y su derecho a la intimidad frente al control empresarial.

Esto, concluye SolóRZANo, lleva a pensar que la mera propiedad empresarial del sistema de comunicación utilizado por el trabajador no es causa habilitante para ignorar sus DDFF. La propiedad empresarial del programa y de la red de comunicación de correo electrónico, sí que habilitan al empresario a establecer las limitaciones de uso que considere oportunas, teniendo en cuenta que el control de la correspondencia electrónica con el exterior procederá únicamente si hay consentimiento o una autorización judicial ${ }^{68}$.

El eje sobre el que han girado los tribunales ha sido, como ya se ha dicho, la tolerancia empresarial derivada de los propios actos de las empresas y, como consecuencia de esta, las expectativas de los trabajadores acerca de su derecho a la intimidad ${ }^{69}$.

Esta expectativa conduce al trabajador a esperar razonablemente que se va a respetar su intimidad en el uso de los medios puestos a su disposición y se convierte en el dato esencial para valorar la licitud o ilicitud del control efectuado por el empresario. De esta forma, se deja en segundo plano el criterio de la propiedad de los medios (ordenadores, internet...), en la que se centraban en un primer momento.

Esta nueva corriente se conecta con la tendencia comunitaria e internacional que también se basa en la expectativa del trabajador para dilucidar los conflictos en ese ámbito.

A nivel comunitario el Grupo de Trabajo «Artículo 29» reconoce que los trabajadores gozan de una legítima expectativa de privacidad en su puesto de trabajo ${ }^{70}$, independientemente de que la propiedad de los medios sea de la empresa.

Por otro lado el TEDH, se basa en el art.8 del Convenio para la Protección de los Derechos Humanos y de las Libertades Fundamentales $(\mathrm{CEDH})^{7 \mathrm{~T}}$ para dilucidar estos conflictos.

Dos de las sentencias más relevantes son: la Sentencia de 25 de junio de I997, Asunto Halford contra Reino Unido y la sentencia de 3 de abril de 2007, Asunto Copland contra Reino Unido.

En el primer caso, Ms. Halford tenía dos teléfonos en su oficina con la finalidad de destinar uno de ellos al uso privado sin ningún tipo de restricción en su utilización, siendo el otro para el uso laboral. Ambos teléfonos fueron interceptados por la empresa, más un tercer teléfono, el de su domicilio.

El Tribunal considera que existe una ausencia de cualquier advertencia a la trabajadora sobre la posibilidad de que el sistema pueda ser objeto de controles, por parte de

\footnotetext{
68 Ibidem, pág. 7.

69 STS de 6 de octubre de 201 , FJ. 4.

70 Grupo de Trabajo «Artículo 29», «Documento de trabajo relativo a la vigilancia de las comunicaciones electrónicas en el lugar de trabajo», 2002, pág. 9.

7I Art.8 CEDH: «I. Toda persona tiene derecho al respeto de su vida privada y familiar, de su domicilio y de su correspondencia. 2. No podrá haber injerencia de la autoridad pública en el ejercicio de este derecho, sino en tanto en cuanto esta injerencia esté prevista por la ley y constituya una medida que, en una sociedad democrática, sea necesaria para la seguridad nacional, la seguridad pública, el bienestar económico del país, la defensa del orden y la prevención del delito, la protección de la salud o de la moral, o la protección de los derechos y las libertades de los demás».
} 
la empresa, ya que el hecho de que exista una separación de líneas telefónicas no es presupuesto que legitime la interferencia de las conversaciones en la línea destinada únicamente a conversaciones de trabajo ${ }^{72}$.

En el asunto Copland, se produce la interceptación de las llamadas y el almacenamiento de información sobre la utilización de la trabajadora para uso personal del teléfono, del correo electrónico y de los datos sobre navegación por internet en el lugar de trabajo sin consentimiento de la afectada. La empresa buscaba determinar si la trabajadora hacía un uso excesivo o no de las instalaciones de la empresa para asuntos personales ${ }^{73}$.

La sentencia aboga por decir, que tanto el correo como la información derivada de la interceptación y almacenamiento del uso de internet en el trabajo deben ser considerados como parte del concepto de vida privada y, por ende del derecho a la intimidad, y hay que tener la misma protección.

VALDÉS DE LA VEGA, en su comentario jurisprudencial considera que no parece que el TEDH «dé relevancia a que el instrumento sea de propiedad del empresario o que se ponga a disposición del trabajador con una finalidad productiva como medio para el cumplimiento de la prestación laboral» ${ }^{74}$.

Esta es la postura que, como ya se ha dicho, comenzaron a tomar los tribunales, afirmación que avala la STS de 26 de septiembre de 2007 , donde el problema resuelto en el recurso se centra en el control que el empresario puede ejercer sobre el uso que da el trabajador al ordenador, cuando los medios informáticos son instrumentos de trabajo puestos a disposición de estos y destinados al cumplimiento de la prestación laboral ${ }^{75}$.

En este caso se produce un despido disciplinario donde la conducta que motiva la sanción es el uso privado que el trabajador da al ordenador facilitado por la empresa como instrumento de trabajo, ya que se detecta la existencia de virus informáticos en dicho ordenador como consecuencia de la navegación por páginas poco seguras de internet.

Apoyándose en las sentencias del TEDH ya vistas, el TS declara el despido como improcedente por la existencia de una lesión del derecho a la intimidad, debido a que la consecuencia del uso personal del ordenador es la existencia de una expectativa de respeto a la información de carácter personal. Solo cuando el trabajador carezca de esa razonable confianza podrá el empresario ejercer sus facultades de control más ampliamente, teniendo siempre presente el límite de la ausencia de violación de los $\mathrm{DDFF}^{76}$.

La STS de 8 de marzo de 20II, también es un claro referente de la apuesta por la buena fe y la trasparencia, pues estableció que si la voluntad del empresario es desplegar su poder de control de manera legítima sobre los medios tecnológicos deberá configurar de antemano las reglas de uso de dichos medios e informar a los trabajadores de la instalación de controles y de los medios que se van a emplear para verificar la corrección de los usos.

\footnotetext{
72 VALDÉs De LA VeGA, B., op. cit., pág. I48.

73 Ibidem, pág. I50.

74 Ibidem, pág. I49.

75 Ibidem, pág. I43.

76 Ibidem, pág. I57.
} 
Expertos en la materia consideran que la solución puede pasar porque la ordenación de estos nuevos medios tecnológicos se remitiera a los procesos de negociación colectiva, recogidos en el art. $85 \mathrm{ET}$, ya que se hace aconsejable que los representantes de los trabajadores y los empresarios negocien unas normas de uso que puedan ser asumidas por ambas partes, para garantizar una debida adecuación de los distintos intereses" .

Aun con todo, lo cierto es que los aspectos relacionados con las nuevas tecnologías se han incorporado de forma muy limitada en algunas negociaciones colectivas, pues las referencias a las TIC en estos instrumentos son escasas o inexistentes en otros convenios.

Según dice el profesor ORTIZ DE SOlóRZANO AurusA, debido al poco éxito de las negociaciones colectivas para llegar a soluciones pactadas se ha incrementado el establecimiento de normas unilaterales por parte de la empresa con respecto al uso de las tecnologías en los llamados, por la doctrina como, códigos éticos, de conducta o manuales de uso. Estos códigos surgidos en relación con la responsabilidad social corporativa recogen las pautas de comportamiento que deben regir la actuación empresarial, donde también se puede incluir en estos, conductas relativas a la utilización de las herramientas tecnológicas puestas a disposición de los trabajadores por la empresa ${ }^{78}$.

No obstante, los códigos de conducta son una fijación unilateral de las reglas de actuación de la empresa y su naturaleza condiciona su alcance y su grado de imperatividad, ya que son fuente de obligaciones para los trabajadores. Consideramos que esto, al ser una decisión unilateral de la empresa puede limitar demasiado los DDFF de los trabajadores, que se verán obligados y sometidos a un control que puede vulnerar su derecho a la intimidad, entre otros. Por lo que la solución debería venir por los convenios colectivos, donde las dos partes están presentes y en igualdad de condiciones, para buscar soluciones que beneficien a todos, sin limitar sus derechos más allá del límite permitido.

La aparición de estos códigos de conducta ha creado una nueva evolución en la jurisprudencia del TS y del TC, a la que no le han faltado críticas.

El pronunciamiento de la STS de 6 de octubre de 20II, considera que «la mera prohibición absoluta de uso de los medios informáticos para fines personales es suficiente para quebrar la expectativa de privacidad que protege al trabajador del control del empresario». Considera por tanto, que una prohibición de este tipo lleva implícita la posibilidad de control, sin que sea necesario que el empresario explicite de modo expreso las comprobaciones que se pueden realizar ${ }^{79}$.

Las críticas a esta sentencia se pueden resumir en la opinión de que la esfera de privacidad en el centro de trabajo del trabajador corre el riesgo de convertirse en un ámbito puramente artificial, ya que el empresario puede negar por su mera voluntad, la existencia de este espacio de intimidad, mediante el simple establecimiento de una prohibición absoluta de uso .

\footnotetext{
77 ORTIZ De SolórZano Aurusa, C., op. cit., pág. 4.

78 Ibidem, pág. 5 .

79 Ibidem, pág. 9.

80 Ibidem, pág. Io.
}

REDUR I3 / 2015 
El TC se pronunció recogiendo este criterio del TS en la sentencia de 7 de octubre de 20I3. En el supuesto no existía, como en la mayoría de los casos, una regulación expresa del uso por los trabajadores de los medios informáticos. Sin embargo, la empresa, en el régimen disciplinario del convenio colectivo aplicable, reconocía como infracción leve el uso particular de los medios tecnológicos puestos a disposición de los trabajadores por parte de la empresa.

De esta previsión, el TC decide que existe una prohibición absoluta de uso extralaboral de los medios informáticos, aunque sea considerada como falta leve como en este caso, por lo que se desvanece para el trabajador la expectativa razonable de tolerancia al uso y, por consiguiente de intimidad ${ }^{8 \mathrm{~T}}$.

No obstante, el TC también somete esta conducta empresarial de fiscalización del correo electrónico y de los medios electrónicos puestos a disposición del trabajador al triple test del juicio de proporcionalidad, conforme a su propia doctrina sobre limitación de DDFF.

Las críticas a estas sentencias relacionadas consideran que existe un retroceso en la protección de los DDFF en la última doctrina del TS, como afirma también el voto particular formulado de uno de los ponentes, frente al pronunciamiento mayoritario del Tribunal ${ }^{82}$.

Esto hace suponer que a la jurisprudencia sobre las TIC le queda aún mucho camino por recorrer, pues los Tribunales aún no tienen claro que postura tomar y la van variando conforme a los criterios que ellos consideran adecuados.

Tras esto, consideramos que para garantizar la licitud de los registros sobre los medios de comunicación empleados por los trabajadores no es suficiente que la empresa establezca unas normas de uso y control, sino que esas medidas deben ser sometidas al juicio de proporcionalidad caso por caso, para una correcta defensa del derecho a la intimidad en el ámbito laboral.

\section{Conclusiones}

Como ya se ha visto a los largo del artículo, los DDFF no se caracterizan por gozar de una extensa regulación. La CE les otorga una posición y protección especiales, pero en general necesitan que el legislador y la jurisprudencia concreten su alcance y ámbito.

El derecho a la intimidad personal se ha ido concretando paulatinamente. Se trata de un derecho inherente al ser humano, que acompaña al individuo siempre.

Sobre esta base, el derecho a la intimidad en el ámbito laboral no abandona al trabajador, no se puede quedar a las puertas del centro de trabajo.

Surge el problema entonces de delimitar el poder de control del empresario (amparado en el art. 20.3 ET) con el derecho a la intimidad del trabajador (recogido en el art. 4.2 e) ET). Y es que estos preceptos no prohíben de manera expresa la instalación y

\footnotetext{
8I Ibidem, pág. Io.

82 Ibidem.
} 
utilización de mecanismos de control y vigilancia consistentes en sistemas de captación de imágenes o grabación de sonidos dentro de los centros de trabajo.

Se encomienda a los órganos jurisdiccionales la tarea de ponderar, en caso de conflicto, en qué circunstancias se puede considerar legítimo su uso por parte del empresario.

Para solucionar cada caso se atenderá a una serie de criterios como son el lugar del centro de trabajo en el que se instalan los sistemas, si la instalación se hace o no indiscriminada y masivamente, si los sistemas son visibles o han sido instalados subrepticiamente, si existen razones de seguridad suficientes, la finalidad real perseguida con la instalación de estos sistemas y el tipo de actividad que se desarrolla.

De otra parte, hay ubicaciones específicas en los centros de trabajo en donde el TC ha reconocido expresamente el derecho a la intimidad del trabajador. Estos son: los lugares de esparcimiento y descanso, vestuarios y lavabos o análogos.

El ET deja claro que está prohibida la instalación en estos lugares de medios de grabación de imágenes o escuchas, ya que se considera lesiva en todo caso del derecho a la intimidad de los trabajadores.

Atendidas estas circunstancias, para resolver las eventuales colisiones de derechos, los tribunales aplican el juicio de proporcionalidad. Para superar este test, se necesitará que la medida cumpla con tres requisitos: el juicio de idoneidad, el juicio de necesidad y el juicio de proporcionalidad en sentido estricto.

Los problemas en el ámbito que nos ocupa pueden surgir también fuera del centro de trabajo. ¿Puede así el empresario con fines disciplinarios confiar a agentes investigadores la tarea de vigilancia de los trabajadores? Esta es una práctica habitual que los tribunales admiten como prueba válida, pero que, sin embargo, parte de la doctrina considera que vulnera el derecho a la intimidad.

Mayores inconvenientes nos encontramos con los nuevos avances informáticos, donde el desarrollo de la jurisprudencia sobre el derecho a la intimidad en el ámbito laboral, no se puede aplicar mediante analogía por tratarse de una realidad nueva de la que el derecho no tiene antecedentes.

Tras el estudio de este tema, se puede comprobar que en lo que se refiere a medidas de seguridad de captación y filmación de imágenes y sonidos, la jurisprudencia ha conseguido acotar el derecho creando una doctrina consolidada. Sin embargo, en lo que se refiere a los nuevos avances informáticos (ordenador, correo electrónico, internet) aún queda mucho trabajo por hacer, dado que son todavía muchos los interrogantes.

En este sentido, los tribunales todavía no han conseguido construir unas pautas generales y seguras para resolver estos conflictos, dado que hasta el momento los pronunciamientos jurisprudenciales son en este ámbito contradictorios.

Por ello, habrá que esperar a ver qué sucede en los años venideros y deberemos estar atentos a la evolución de los conflictos, por lo demás, cada vez más frecuente, del derecho a la intimidad en el ámbito laboral en relación con las nuevas tecnologías. 